\title{
Nutrient Intake and Immune Status of HIV Sero-positive Patients in a Comprehensive Care Clinic at Chulaimbo Sub-district Hospital, Kenya
}

\author{
Agatha Christine Onyango ${ }^{1,}$, , Mary Khakoni Walingo ${ }^{1}$, Grace Mbagaya ${ }^{2}$, Rose Kakai ${ }^{3}$ \\ ${ }^{1}$ Department of Nutrition and Health, School of Public Health and Community Development, Maseno University, Maseno, Kenya \\ ${ }^{2}$ Department of Family and Consumer Sciences, School of Agriculture and Biotechnology, Moi University, Eldoret, Kenya \\ ${ }^{3}$ Department of Microbiology, School of Medicine, Maseno University, Maseno, Kenya
}

\author{
Email address: \\ acatieno@yahoo.com (A. C. Onyango)
}

\section{To cite this article:}

Agatha Christine Onyango, Mary Khakoni Walingo, Grace Mbagaya, Rose Kakai. Nutrient Intake and Immune Status of HIV Sero-positive Patients in a Comprehensive Care Clinic at Chulaimbo Sub-district Hospital, Kenya. Journal of Food and Nutrition Sciences.

Vol. 3, No. 6, 2015, pp. 209-215. doi: 10.11648/j.jfns.20150306.12

\begin{abstract}
Human immunodeficiency virus (HIV) and nutrition status of human are linked to HIV infection and poor nutrient intake can speed the disease progress. Both macro-and micronutrient deficiencies could impair host immune functions and promote viral replication and pathogenicity, thus potentially affecting the clinical course of HIV infection. The objective was to assess the immune status and nutrient intake of HIV sero-positive patients. A prospective cohort study was conducted on 497 People Living with HIV and AIDS (PLWHA) attending clinic at Chulaimbo Sub-district hospital in Kenya. $\mathrm{CD}_{4}$ cell count was used to assess immune status and a 24-hour dietary recall survey to capture the average macronutrient and micronutrient intake of the patients. Nutrient intake was estimated using a diet history in combination with a standardized food frequency questionnaire. The study setting was with the Academic Model for Prevention and Treatment of HIV/AIDS (AMPATH) clinic at Chulaimbo Sub-district hospital, Kisumu West District, Kenya, and comprised of 497 adults aged 18-60 years. After 6 months, it was found that there was a higher proportion of the males in stage three and four $65(61.9 \%)$ compared to the females $173(44.3 \%)$ Majority of the patients were within the normal range for WBC $\left(4000-11000 \mathrm{cell} / \mathrm{mm}^{3}\right)$ and platelet count (130000-440000 cell/ $\left./ \mathrm{mm}^{3}\right)$ but there was a drop below the normal range for $\mathrm{CD}_{4}$ cell count $\left(600-1200 \mathrm{cell} / \mathrm{mm}^{3}\right)$ and $\mathrm{CD}_{4}$ cell percentage (30-60\%) were below the normal range. There were more male patients in the third (severe) category compared to the female patients. There was inadequate nutrient intake among the mild, moderate and severe categories with exception of the thiamine intake. The results confirm that majority of the HIV/AIDS patients from this population are malnourished and majority of the male patients had their $\mathrm{CD}_{4}$ below the normal range. Adequate nutritionist important and nutrient supplementation of HIV/AIDS patients should be considered, as this might lead to improved immune function in these patients.
\end{abstract}

Keywords: Nutrient Adequacy, $\mathrm{CD}_{4}$, Food Group, Immune Status, HIV

\section{Introduction}

There exists a complex interaction between Human Immuno-deficiency Virus (HIV), infection and immune function, with a dominant effect of HIV infection on nutritional status (1). The influence of nutrition on immune function generally shows that suboptimal nutrition results in immunological deficiencies (1). Nutrient deficiencies cause immunosuppression and increase susceptibility to infections. This results in loss of immune cell function which allows intrusion by several different infectious agents. Thus there is a reduction of the ability of the body to fight disease and subsequent acquisition of opportunistic infections (2).

Nutrients that play a big role in immune function include: protein, total energy, lipids, vitamins and minerals (3). Normal antibody production, phagocytic cell and Tlymphocyte functions depend on the adequate intake of energy, protein, fat, minerals and vitamins (4).Optimal nutrition alters immunological function and therefore disease states. In HIV infection this interaction affects the body's immune status predisposing individuals to infections. Proteins play roles as structural components of tissues and also antibodies, cytokines, acute-phase proteins, components of the complement pathways, transcription factors and 
enzymes (5). Deficiency of protein could lead to immunologically important changes in enzyme-dependent activation, antioxidant protection, complement activation, antibody-mediated virus neutralization and intercellular communication via cytokines (6). During HIV infection, there is faster metabolism and increased energy expenditure which results in weight loss that tends to be in the form of lean tissue, such as muscle (3). Weight loss strongly predicts illness or death among people with HIV (6).

Good nutrition is vital for health, and the immune function is affected with inadequate nutrient intake and this could lead to infections. In disease states like HIV infection inadequate nutrient intake and micronutrients can have an adverse effect on the immune function. When macronutrient intake is insufficient to meet metabolic needs, protein-calorie malnutrition (PCM) and deficiencies of micronutrients develop (3). These deficiencies impair both the synthesis of molecules necessary for the immune response and the function of immune-related enzyme systems (5). When this impairment occurs the individual is predisposed to opportunistic infections. In HIV disease, the presence of malnutrition strongly predicts patient survival independent of CD4 (Cluster of Differentiation 4) T-lymphocyte counts (5). Clinical deficiencies of some nutrients occur rapidly in response to dietary deficiencies, malabsorption, or altered metabolism, while those having a storage form in the body may take longer. Malnutrition alters the immune function with a subsequent increase in susceptibility to infections, faster disease progression, reduced functional status, quality of life, and increased morbidity and mortality (7).The presenting symptoms of malnutrition typically include weight loss, a change in body habitus (loss of lean body mass) or a change in functional status (inability to perform daily activities) (3).

\section{Materials and Methods}

Study site and population: This study was carried out in Kisumu West District is in Nyanza Province. Chulaimbo Sub-district hospital is located along Kisumu-Busia Road about $17 \mathrm{~km}$ from Kisumu town. This prospective study was performed in the AMPATH clinic at Chulaimbo outpatient department and social work department. The study population was selected among HIV sero-positive patients attending the outpatient clinic from February 2010 to July 2010, who gave informed written consent. Patients requiring hospitalization were excluded. The inclusion criteria was male and female patients between 18 and 60 years of age that were HIV sero-positive, willing to sign the statement of informed consent and had been enrolled in the AMPATH clinic as outpatients for the last six (6) months preceding the study. The study was approved by the Institutional Review Ethics Committee of School of Medicine, Moi University, (FAN: IREC 000470).

This study was conducted within the framework of AMPATH (Academic Model for Prevention and Treatment of HIV/AIDS) clinic at Chulaimbo Sub-district hospital, Kenya.
The study adopted a prospective cohort research design among the study population. A sample size of 497 was randomly chosen from a sample frame of 9100 patients aged 18 to 60 years, this was done with the use of random table numbers. Patients whose ages fell outside $18-60$ years age bracket, inpatient, PMTCT mothers and those who had not been enrolled in the AMPATH clinic for the last six (6) months that preceded the study did not participate in the study. Of the 497 patients, 392 female and 105 male were included in the study. The proposal of this study was approved by Institutional Review Ethics Committee of School of Medicine, Moi University, (FAN: IREC 000470) and informed written consent was obtained from all the patients.

\subsection{Dietary Assessment}

Dietary intake assessment was undertaken using a 24hour recall survey form by expert nutritionists, with at least five years of experience in the nationwide food consumption survey project (8).The 24-hour recalls was administered once on every visit to the clinic for six months. The 24-hour recall was based on actual intake and used to estimate absolute rather than relative intake (9). The 24hour recall method is susceptible to recall bias, both for identification of foods eaten and for quantification of portion sizes. Collecting dietary data by highly trained interviewers in this study reduced this type of error. The 24hour dietary recall described the reported intakes from midnight to midnight, meal after meal. Individuals were questioned as to whether the day of recalls was a usual day or not, hence showed the usual intake of patients. Standard reference tables were used to convert household portions to grams for computerization (10). After coding, the 24 hour dietary recall survey form was linked to a nutrient database (Nutritionist III) and nutrient intakes. The data related to Nutritionist III was modified according to the Food Composition Tables by Sehmi (11).

\subsection{Measures of Immune System Integrity}

The patient's WHO staging was first assessed based on the clinical symptoms using the WHO (12) guidelines. The immunological assessment methods included CD4 cell count which yielded the actual CD4 cell count and CD4 cell percentage $(\%)$ of the patients. They are cells marked with specific molecules on their surface (called cluster of differentiation, or $\mathrm{CD}$ ) that identify their immune function. The patients were categorized into three main groups according to their CD4 cell count; mild patients (category -1) were those who had a CD4 cell count above 500 cells $/ \mathrm{mm}^{3}$ (cells per cubic millimeter of blood), moderate patients had a CD4 cell count between 200 to 499 cells $/ \mathrm{mm}^{3}$ on ART or not (category - 2) and severe patients had a CD4 cell count below 200 cells $/ \mathrm{mm}^{3}$ (category -3 ).

Data collection: The study was performed two days a week. Each patient was recruited once, on his or her first visit during the study period. Validated interview schedule 
were used to determine the socio-demographic profile. The patients were first sensitized on the objectives and importance of the study during the health talks in the morning before the clinic sessions started. The researcher with the help of the psycho social worker gave a nutrition/health introductory talk. The patients included in the study had their files and clinic cards tagged with labeled green stickers. This was done to be able to identify the patients on every visit to the clinic for the period of the study. Physicians on duty in the outpatient department on these selected days attended to the patients after the interviews and gave them a return date of one month. This study used the CD4 cell count to classify the patients into three categories; < 200 cells/mm3 was severe, 200-499 cells $/ \mathrm{mm} 3$ as moderate and $>500$ cells $/ \mathrm{mm} 3$ as mild. Severe immunosuppression was considered as 3 , moderate as 2 and mild as 1.

Statistical analysis: Data were entered in Microsoft excel 2007 then imported to SPSS version 15.0 and the alpha level $(\alpha)$ was set at 0.05 . Data was analyzed quantitatively using descriptive and inferential statistics. Analysis of variance (ANOVA) was used to determine association between immune status and nutrition. A Post Hoc test was performed to find out the source of the difference in the nutrient status, nutrient intake and nutritional status across the mild, moderate and severe categories.

\section{Results}

\subsection{Staging and Categorization}

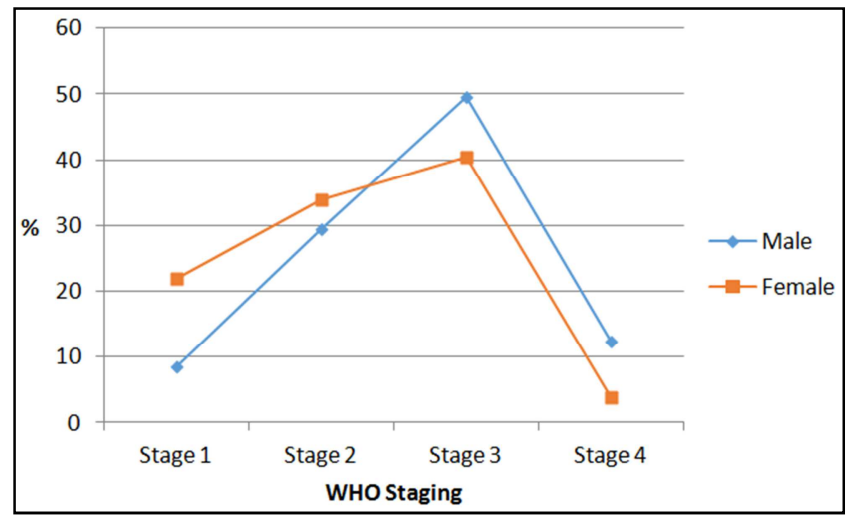

Figure 1: WHO Staging at Baseline by Sex.

Assessment of the immune integrity of HIV patients in samples collected at baseline was based on WHO staging. Ninety five (19.1\%) were in stage-1 (asymptomatic), 164 $(33.0 \%)$ in stage - 2 (Mild symptoms), 210 (42.3\%) in stage - 3 (Advanced symptoms) and $28(5.6 \%)$ in stage - 4 (Severe symptoms). Results in Figure 1 show that 86 $(21.9 \%)$ females and $9(8.6 \%)$ males were in stage one, $133(33.9 \%)$ females and $31(29.5 \%)$ males were in stage two, $158(40.4 \%) \mathrm{s}$ and $52(49.5 \%)$ males were in stage three and $15(3.8 \%)$ females and $13(12.4 \%)$ males were in stage four. There was a higher proportion of the males in stage three and four $65(61.9 \%)$ compared to the females
$173(44.3 \%)$ as illustrated in Figure 1.The immune integrity of the patients in terms of CD4 cell count was classified into three independent categories at baseline.There was $89(17.9 \%)$ in the severe category, 252 $(50.7 \%)$ in the moderate, and $156(31.3 \%)$ in mild. There was a higher percentage of males in the severe category where majority of the patients had their CD4 cell count below $<200 \mathrm{~mm}^{3}$, as illustrated in Figure 1 .

\subsection{Immune Status Measures}

White blood cells (WBC), platelets, CD4 cell count and CD4 percentage (\%) were measured to assess the immune integrity at baseline as shown in Table 1.1. The mean WBC was $5503.32 \mathrm{cell} / \mathrm{mm}^{3}$; mean platelets count 265957.46 cell $/ \mathrm{mm}^{3}$, mean CD4 cell count $431 \mathrm{cell} / \mathrm{mm}^{3}$ and mean CD4 percentage $19.3 \%$. Majority of the patients were within the normal range for WBC (4000-11000 cell $\left./ \mathrm{mm}^{3}\right)$ and platelet count $\left(130000-440000 \mathrm{cell} / \mathrm{mm}^{3}\right)$ but there was a drop below the normal range for CD4 cell count $\left(600-1200\right.$ cell $\left./ \mathrm{mm}^{3}\right)$ and CD4 cell percentage $(30-60 \%)$ were below the normal range.

\subsection{Relationship Between WHO Staging Category and Sex}

Chi-square test was carried out to establish the relationship between WHO staging and sex as illustrated in Figure 2. Results revealed a significant relationship between WHO staging and sex, $\left(\chi_{\text {obt }}^{2}=18.070, \mathrm{n}=497, d f=1, p<0.0001\right)$. There were more male patients $(61.9 \%)$ in the third and fourth WHO staging compared to the female patients (44.1\%). There was a significant relationship between age and HIV/AIDS status, $\left(\chi_{\text {obt }}^{2}=24.636, \mathrm{n}=497, d f=1, p<0.0001\right)$. There were more male patients in the third (severe) category compared to the female patients.

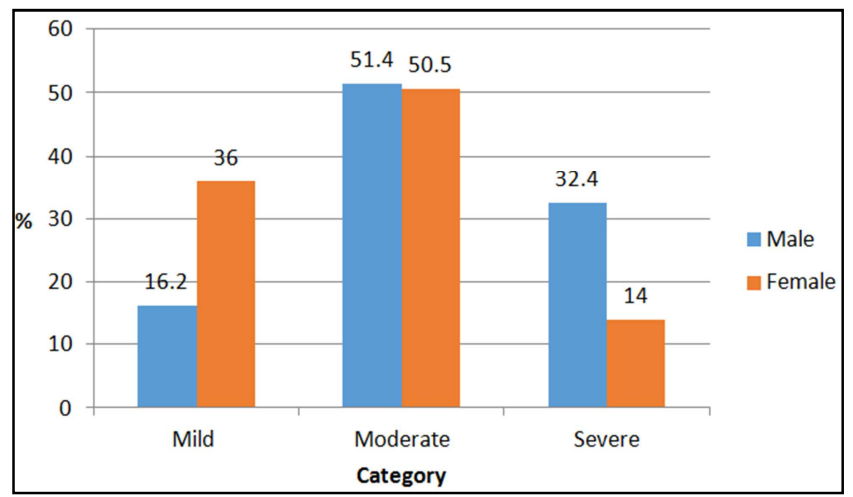

Figure 2: Distribution of CD4 Cell Count by Immune Status Category at Baseline.

\subsection{Association between Nutrition and CD4 Cell Count among HIV Sero-positive Patients}

The study focused on the mild $\left(<200\right.$ cells $\left./ \mathrm{mm}^{3}\right)$, moderate $\left(200-499 \mathrm{cell} / \mathrm{mm}^{3}\right)$ and severe $>500$ cells $\left./ \mathrm{mm}^{3}\right)$ categories in assessing the association between nutrition, infection and immune factors among HIV sero-positive patients. There was inadequate nutrient intake among the mild, moderate and 
severe categories with exception of the thiamine intake, as shown in Table 1.2.

\subsection{Association Between CD4 Cell Count and Nutrient Intake over the Study Period}

One-way repeated measures ANOVA were conducted to compare the association between CD4 cell levels and nutrient intake over six months. The ANOVA was based on the following nutrients: energy, protein, iron, calcium, vitamin A, vitamin $\mathrm{C}$, thiamine, riboflavin and niacin. Results show that there was a statistically significant association between CD4 cell count and nutrient intake levels of energy $(p=0.005)$, protein $(p<0.0001)$, calcium $(p<0.0001)$, vitamin A $(p<$ $0.0001)$, riboflavin $(p<0.0001)$ and niacin $(p<0.0001)$, Table 1.3.

Additional results demonstrated that there was a statistically significant association between CD4 cell count and nutrient intake across the three categories of CD4 cell count between February and July. In addition, a significant association occurred between CD4 cell count and nutrient intake in the levels of protein between February and June ( $p$ $=0.020)$, calcium between February and March $(p=0.001)$, February and April $(p=0.001)$, February and May ( $p=$ $0.003)$, February and June $(p<0.0001)$, and February and July $(p=0.002)$, vitamin $\mathrm{C}$ between February and March ( $p$ $=0.001)$, February and April $(p=0.024)$, February and May $(p=0.028)$ and February and July $(p=0.027)$; and thiamine between February and June $(p=0.013)$, March and June $(p=$ $0.042)$, May and June ( $p=0.001)$.

One-way repeated measures ANOVA were conducted to compare the association between CD4 cell levels and nutrient intake over six months. The association between CD4 cell count and nutrient intake was compared across the mild, moderate and severe categories. There was a statistically significant difference in the mean nutrient intake of energy [F $(1,2)=5.38, p=0.004]$, protein $[\mathrm{F}(1,3)=12.99, p=0.001]$, protein $[\mathrm{F}(2,3)=12.99, p<0.0001]$, calcium $[\mathrm{F}(1,2)=18.22$, $\mathrm{p}<0.0001]$, calcium $[\mathrm{F}(1,3)=18.22, p<0.0001]$, vitamin A $[\mathrm{F}(1,2)=8.656, p<0.0001]$, riboflavin $[\mathrm{F}(1,3)=11.51, p<$ $0.0001)$, riboflavin $[\mathrm{F}(2,3)=11.511, p<0.0001]$, niacin $[\mathrm{F}(1$, $2)=7.99, p=0.007]$, niacin $[\mathrm{F}(2,3)=7.99, p=0.002]$, as shown in Table 1.4.

Further analysis based on Tukeypost-hoc test showed that the energy (Kcal) was lower in the mild (1679.62 \pm 1015.83$)$ and severe $(1644.24 \pm 614.95)$ categories compared to the moderate $(1579.60 \pm 511.40)$ category, protein was lower in severe $(41.99 \pm 11.54)$ and mild $(39.73 \pm 12.05)$ compared to moderate $(38.95 \pm 11.82)$, iron was lower in severe $(10.60 \pm$ $3.17)$ and moderate $(10.53 \pm 3.27)$ compared to mild $(10.29 \pm$ $3.16)$, calcium was lower in mild $(568.61 \pm 338.69)$ and moderate $(498.22 \pm 312.04)$ compared to mild (481.96 \pm 291.25), vitamin A was lower mild $(5501.85 \pm 8449.98)$ and severe $(4727.76 \pm 4515.01)$ compared to moderate (4423.10 $\pm 5031.34)$, vitamin $C$ was lower mild $(52.87 \pm 24.53)$ and moderate $(51.59 \pm 26.04)$ compared to severe $(51.07 \pm 25.39)$, thiamine was lower in mild $(1.67 \pm 0.70)$ and moderate $(1.72$ $\pm 0.72)$ compared to severe $(1.71 \pm 0.55)$, riboflavin was lower in mild $(0.44 \pm 0.42)$ and moderate $(0.43 \pm 0.39)$ compared to severe $(0.52 \pm 0.45)$, niacin was lower in mild $(10.64 \pm 4.50)$ and moderate $(10.10 \pm 4.10)$ compared to severe $(10.84 \pm 3.92)$.

Table 1.1: Distribution of HIV Sero-positive Patients by Immune Status Measures and Sex (n=497).

\begin{tabular}{lllll}
\hline Immune status & Sex & N & Mean $( \pm$ SD) & Normal range Measures \\
\hline WBC $\left(\right.$ cell/ $\left./ \mathrm{mm}^{3}\right)$ & Male & 105 & $5749.05( \pm 2440.648)$ & $4000-11000$ \\
& Female & 392 & $5564.05( \pm 3415.409)$ & \\
Platelets $\left(\mathrm{cell} / \mathrm{mm}^{3}\right)$ & Male & 105 & $256398.65( \pm 153178.31)$ & $130000-440000$ \\
& Female & 392 & $268517.86( \pm 135761.76)$ & \\
$\mathrm{CD} 4\left(\mathrm{cell} / \mathrm{mm}^{3}\right)$ & Male & 105 & $314.35( \pm 193.179)$ & $600-1200$ \\
& Female & 392 & $462.36( \pm 267.16)$ & $30-60$ \\
$\mathrm{CD} 4 \%(\%)$ & Male & 105 & $15.39( \pm 9.92)$ & \\
& Female & 392 & $20.36( \pm 8.38)$ & \\
\hline
\end{tabular}

Key: WBC $=$ White Blood Cells, $C D=$ Cluster of Differentiation.

Table 1.2: Pattern of Nutrient Intake across Categories of Immune Status of HIV Sero-positive Patients over the Study Period ( $n=497)$.

\begin{tabular}{|c|c|c|c|c|c|}
\hline Nutrients & Normal range & Category & & & Total \\
\hline & & $\begin{array}{l}\text { Mild }>500 \text { cells } / \mathrm{mm}^{3} \\
\text { No }(\%)\end{array}$ & $\begin{array}{l}\text { Moderate 200-499cells } / \mathrm{mm}^{3} \\
\text { No (\%) }\end{array}$ & $\begin{array}{l}\text { Severe }<200 \text { cells } / \mathrm{mm}^{3} \\
\text { No }(\%)\end{array}$ & No $(\%)$ \\
\hline Energy (Kcal) & $2100-3000$ & & & & \\
\hline$<2100$ & & $116(74.3 \%)$ & $205(81.3 \%)$ & $74(83.1 \%)$ & $395(79.4 \%)$ \\
\hline $2100-3000$ & & $40(25.7 \%)$ & $43(18.7 \%)$ & $15(16.9 \%)$ & $102(20.6 \%)$ \\
\hline$>3000$ & & $0(0.0 \%)$ & $0(0.0 \%)$ & $0(0.0 \%)$ & $0(0.0 \%)$ \\
\hline Protein (g) & $46-56$ & & & & \\
\hline$<46$ & & $93(59.6 \%)$ & $171(67.9 \%)$ & $58(65.2 \%)$ & $322(64.8 \%)$ \\
\hline $46-56$ & & $57(36.5 \%)$ & $72(28.6 \%)$ & $28(31.5 \%)$ & $157(31.6 \%)$ \\
\hline$>56$ & & $6(3.9 \%) 9$ & $(3.5 \%)$ & $3(3.3 \%)$ & $18(3.6 \%)$ \\
\hline
\end{tabular}




\begin{tabular}{|c|c|c|c|c|c|}
\hline \multirow[t]{2}{*}{ Nutrients } & \multirow[t]{2}{*}{ Normal range } & \multicolumn{3}{|l|}{ Category } & \multirow{2}{*}{$\begin{array}{l}\text { Total } \\
\text { No }(\%)\end{array}$} \\
\hline & & $\begin{array}{l}\text { Mild }>500 \text { cells } / \mathrm{mm}^{3} \\
\text { No }(\%)\end{array}$ & $\begin{array}{l}\text { Moderate } 200-499 \text { cells } / \mathrm{mm}^{3} \\
\text { No }(\%)\end{array}$ & $\begin{array}{l}\text { Severe }<200 \text { cells } / \mathrm{mm}^{3} \\
\text { No }(\%)\end{array}$ & \\
\hline Total & & $156(100 \%)$ & $252(100 \%)$ & $89(100 \%)$ & $497(100 \%)$ \\
\hline Iron (mg) & $8-18$ & & & & \\
\hline$<8$ & & $53(34.0 \%)$ & $99(39.3 \%)$ & $30(33.7 \%)$ & $182(36.6 \%)$ \\
\hline $8-18$ & & $103(66.0 \%)$ & $150(59.5 \%)$ & $59(66.3 \%)$ & $312(62.8 \%)$ \\
\hline$>18$ & & $0(0.0 \%)$ & $3(1.2 \%)$ & $0(0.0 \%)$ & $3(0.6 \%)$ \\
\hline Total & & $156(100 \%)$ & $252(100 \%)$ & $89(100 \%)$ & $497(100 \%)$ \\
\hline Calcium (mg) & 1200 & & & & \\
\hline$<1200$ & & $152(97.4 \%)$ & $251(99.6 \%)$ & $88(98.9 \%)$ & $491(98.8 \%)$ \\
\hline$>1200$ & & $4(2.6 \%)$ & $1(0.4 \%)$ & $1(1.1 \%)$ & $6(1.2 \%)$ \\
\hline Total & & $156(100 \%)$ & $252(100 \%)$ & $89(100 \%)$ & $497(100 \%)$ \\
\hline Vitamin A (IU) & 17000 & & & & \\
\hline$<17000$ & & $154(98.7 \%)$ & $250(99.2 \%)$ & $88(98.9 \%)$ & $49299.0 \%)$ \\
\hline$>17000$ & & $2(1.3 \%)$ & $2(0.8 \%)$ & $1(1.1 \%)$ & $5(1.0 \%)$ \\
\hline Total & & $156(100 \%)$ & $252(100 \%)$ & $89(100 \%)$ & $497(100 \%)$ \\
\hline Vitamin C (mg) & $75-90$ & & & & \\
\hline$<75$ & & $119(76.3 \%)$ & $198(76.6 \%)$ & $65(73.0 \%)$ & $382(76.9 \%)$ \\
\hline $75-90$ & & $34(21.8 \%)$ & $44(17.4 \%)$ & $17(19.1 \%)$ & $95(19.1 \%)$ \\
\hline$>90$ & & $3(1.9 \%)$ & $10(4.0 \%)$ & $7(7.9 \%)$ & $20(4.0 \%)$ \\
\hline Total & & $156(100 \%)$ & $252(100 \%)$ & $89(100 \%)$ & $497(100 \%)$ \\
\hline Thiamine (mg) & $1.1-1.2$ & & & & \\
\hline$<1.1$ & & $29(18.6 \%)$ & $45(17.9 \%)$ & $13(14.6 \%)$ & $87(17.5 \%)$ \\
\hline $1.1-1.2$ & & $5(3.2 \%)$ & $10(3.9 \%)$ & $3(3.4 \%)$ & $18(3.6 \%)$ \\
\hline$>1.2$ & & $122(78.2 \%)$ & $197(78.2 \%)$ & $73(82.0 \%)$ & $392(78.9 \%)$ \\
\hline Total & & $156(100 \%)$ & $252(100 \%)$ & $89(100 \%)$ & $497(100 \%)$ \\
\hline Riboflavin (mg) & $1.1-1.3$ & & & & \\
\hline$<1.1$ & & $1519(.8 \%)$ & $244(96.8 \%)$ & $85(95.5 \%)$ & $480(96.6 \%)$ \\
\hline $1.1-1.3$ & & $0(0.0 \%)$ & $2(0.9 \%)$ & $0(0.0 \%)$ & $2(0.4 \%)$ \\
\hline$>1.3$ & & $5(3.2 \%)$ & $6(2.3 \%)$ & $4(4.5 \%)$ & $15(3.0 \%)$ \\
\hline Total & & $156(100 \%)$ & $252(100 \%)$ & $89(100 \%)$ & $497(100 \%)$ \\
\hline Niacin (mg) & $14-16$ & & & & \\
\hline$<14$ & & $135(86.5 \%)$ & $232(92.1 \%)$ & $78(87.6 \%)$ & $445(90.0 \%)$ \\
\hline $14-16$ & & $15(9.6 \%)$ & $15(6.0 \%)$ & $8(9.0 \%)$ & $38(7.6 \%)$ \\
\hline$>16$ & & $6(3.9 \%)$ & $5(1.9 \%)$ & $3(3.4 \%)$ & $14(2.4 \%)$ \\
\hline Total & & $156(100 \%)$ & $252(100 \%)$ & $89(100 \%)$ & $497(100 \%)$ \\
\hline
\end{tabular}

Table 1.3: Mean Nutrient Intake across CD4 Cell Count Levels.

\begin{tabular}{|c|c|c|c|c|c|}
\hline Nutrients & Sex & Mean values & $d f$ & $\mathbf{F}$ & Sig \\
\hline \multirow[t]{2}{*}{ Kcal } & Male & 1555.93 & 2 & 5.38 & $0.005^{*}$ \\
\hline & Female & 1596.19 & & & \\
\hline \multirow[t]{2}{*}{ Protein } & Male & 40.43 & 2 & 12.99 & $0.000^{*}$ \\
\hline & Female & 40.83 & & & \\
\hline \multirow[t]{2}{*}{ Iron } & Male & 10.35 & 2 & 2.21 & 0.110 \\
\hline & Female & 10.54 & & & \\
\hline \multirow[t]{2}{*}{ Calcium } & Male & 415.10 & 2 & 18.22 & $0.000 *$ \\
\hline & Female & 461.41 & & & \\
\hline \multirow[t]{2}{*}{ Vitamin A } & Male & 3874.14 & 2 & 8.66 & $0.000 *$ \\
\hline & Female & 4535.39 & & & \\
\hline \multirow[t]{2}{*}{ Vitamin C } & Male & 49.54 & 2 & 1.07 & 0.343 \\
\hline & Female & 47.06 & & & \\
\hline \multirow[t]{2}{*}{ Thiamine } & Male & 1.63 & 2 & 1.69 & 0.184 \\
\hline & Female & 1.76 & & & \\
\hline \multirow[t]{2}{*}{ Riboflavin } & Male & 0.44 & 2 & 11.51 & $0.000 *$ \\
\hline & Female & 0.42 & & & \\
\hline
\end{tabular}


Table 1.4: Post-hoc Results of Nutrient Intake across CD4 Cell Count Levels.

\begin{tabular}{lll}
\hline Nutrients & Mean difference (MD) & Sig \\
\hline Energy (Kcal) & & \\
Mild/moderate & 100.02 & $0.004^{*}$ \\
Mild/severe & 35.38 & 0.660 \\
Moderate/severe & -64.64 & 0.202 \\
Protein & & \\
Mild/moderate & 0.77 & 0.261 \\
Mild/severe & -2.27 & 0.001 \\
Moderate/severe & -3.04 & $0.000^{*}$ \\
Calcium & & \\
Mild/moderate & 70.39 & $0.000^{*}$ \\
Mild/severe & 86.64 & $0.000^{*}$ \\
Moderate/severe & 16.26 & 0.566 \\
Vitamin A & & \\
Mild/moderate & 1078.76 & $0.000^{*}$ \\
Mild/severe & 774.10 & 0.058 \\
Moderate/severe & -304.66 & 0.596 \\
Riboflavin & & \\
Mild/moderate & 0.12 & 0.750 \\
Mild/severe & -0.08 & $0.000^{*}$ \\
Moderate/severe & -0.10 & $0.000^{*}$ \\
Niacin & & \\
Mild/moderate & 0.53 & $0.007^{*}$ \\
Mild/severe & -0.20 & 0.668 \\
Moderate/severe & -0.73 & $0.002^{*}$ \\
\hline
\end{tabular}

$* \alpha=0.05$, Mild $=\mathrm{CD} 4$ cell count $>500$ cells $/ \mathrm{mm}^{3}$, Moderate $=\mathrm{CD} 4$ cell count between 200 and 499 cells $/ \mathrm{mm}^{3}$, Severe $<200$ cells $/ \mathrm{mm}^{3}$

\section{Discussion}

The links between HIV and nutritional status run both ways. Dietary inadequacy including loss of diversity represents a key outcome of changes as it precipitates challenges to human health (13). A well-nourished person can also heal quickly from an infection (14). This study established that there was an association between nutrition and immune factors as is shown in the results that majority of the patients in the severe category had inadequate dietary intake compared to those in the mild and moderate categories. This suggests that the effect of nutrition on immunity has several implications in HIV sero-positive patients. Several minerals and vitamins have essential roles in metabolic pathways and immune cell functions. The deficiencies of these micronutrients complicate malnutrition and other systemic diseases (3). In assessing immunity progress this study established that majority of the patients were in WHO stage three with a mean CD4 count of 431 cells $/ \mathrm{mm}^{3}(314.35$ \pm 193.17 in males and $462.36 \pm 267.16$ in females) and the nutrient intake was inadequate except for thiamine (both in males and females) and iron (males). Studies have shown that deficiencies of nutrients may affect the immune function in ways that may influence viral expression and replication, which further affect progression of HIV disease and mortality of the patient (4). HIV infection compromises the nutritional status of infected persons and in turn poor nutritional status can affect the progression of HIV infection (15).

Both macronutrients and micronutrients play an important role in maintaining nutritional status, and probably delay disease progression. Irrespective of the availability of antiretroviral therapy, an adequate, well balanced diet, providing required foods and consequently adequate nutrients to meet the increased requirements of HIV and AIDS, is an important measure in maintaining nutritional health in people living with HIV and AIDS. It is envisaged that the high dietary intake of major macronutrients and micronutrients will help in maintaining the nutritional status and in reducing wasting in the patients (4). The results thus suggest that nutrition may be associated with immune status of HIV sero-positive patients. This implies that nutrition is important at all times for an HIV sero-positive patient. Specifically, the consumption of all nutrients in their adequate proportions may assist in the management of HIV infection. The results revealed that the severe category had a higher percentage of nutrient inadequacy compared to those in the mild and moderate categories. The patients in severe category had a lower CD4 cell count and thus prone to opportunistic infections. The differences between nutrient intake and immune status means are not likely due to chance but are probably due to nutrient intake. Infections may occur irrespective of the CD4 cell count levels of the HIV patient, in this study the infection rate was higher in the severe category (CD4 cell count $<200$ cells $/ \mathrm{mm}^{3}$ ).

\section{Conclusion}

Most of the HIV patients were symptomatic in WHO clinical stage 3 with a CD4 cell count of less than 500 
cells $/ \mathrm{mm}^{3}$; this is an indication of immunosuppression in the patients. The female patients had significantly higher CD4 cell count than the male patients. Most of the male patients were in WHO stage 3 and WHO stage 4. Nutrients have fundamental and regulatory influences on the immune response of most organs in the body and, therefore, on host defense. In addition to the effect of nutrition during development, the local impact of different dietary and antigenic elements on the regional immune system contributes to potential diversion of the two systems throughout life.

\section{Acknowledgements}

This study was made possible by Maseno Universitythrough provision of the facilities for the research. Iwould like to thank the AMPATH clinic staff, in-charge at Chulaimbo hospital and all the participants in the study. Above all, thanks to God Almighty for sufficient grace and strength.

\section{References}

[1] Macallan, D. C. (1999). Nutrition and Immune Function in Human Immunodeficiency Virus Infection. Paper Presented at the Proceedings of the Nutrition Society.

[2] Hoffmann, C., Rockstroh, J. K., \& Kamps, B. S. (2007). HIV Medicine 2007.

[3] Baum, M. K., \& Shor-Posner, G. (1998). Micronutrient Status in Relationship to Mortality in HIV-1 Disease. Nutrition Reviews, 56 (1), S135-S139.

[4] Semba, R. D., \& Tang, A. M. (1999). Micronutrients and the Pathogenesis of Human Immunodeficiency Virus Infection. British Journal of Nutrition, 81, 181-189.

[5] Friis, H. (2006). Micronutrient interventions and HIV infection: A Review of Current Evidence Interventions aux Micronutriments dans l'infection VIH: Une Revue de l'évidence Courante Intervenciones Con Micronutrientes e Infección Por VIH: Una Revisión de la Evidencia Actual. Tropical Medicine \& International Health, 11 (12), 1849-1857.

[6] Gershwin, E. M., German, B. J., \& Keen, L. C. (Eds.). (2000). Nutrition and Immunology: Principles and Practice. Totowa, New Jersey. Humana Press. Inc.

[7] Schwarz, K. B. (1996). Oxidative Stress during Viral Infection: A Review, Free Radical Biology and Medicine, 5, 641-649.

[8] Resnicow, K., Odom, E., Wang, T., Dudley W.N., Mitchell D., Vaughan R., et al. (2000). Validation of Three Food Frequency Questionnaires and 24-Hour Recalls with Serum Carotenoid Levels in a Sample of African-American Adults. American Journal of Epidemiology, 152 (11), 1072-1080.

[9] Hammond, K., A. (2004). Dietary and Clinical Assessment (11th Ed. Vol. 372). Philadelphia: WB Saunders Co: 372.

[10] Hatløy, A., Torheim, L. E., \& Oshaug A. (1998). Food Variety - A Good Indicator of Nutritional Adequacy of the Diet? A Case Study from an Urban Area in Mali, West Africa. European Journal of Clinical Nutrition, 52, 891-898.

[11] Sehmi, J. R. (1993). National Food Composition Tables and the Planning of Satisfactory Diets in Kenya. Nairobi, Kenya: Government Printer.

[12] WHO. (2005). Consultation on Nutrition and HIV/AIDS in Africa. Durban, South Africa: Consultation on Nutrition and HIV/AIDS in Africa, Durban, South Africa, April $10^{\text {th }}-13$ th, 2005.

[13] Johns, T. (2001). Dietary Diversity, Global Change, and Human Health. Quebec, Canada Macdonald University, STE.

[14] FANTA. (2004). A guide for Nutrition Care and Support. Washington DC: Academic for Educational Development.

[15] Friis, H., \& Michaelsen, K. F. (1998). Micronutrients in HIV Infection: A Review. European Journal of Clinical Nutrition, 52, 157-163. 